Tropical Journal of Pharmaceutical Research December 2012; 11 (6): 917-924

(C) Pharmacotherapy Group,

Faculty of Pharmacy, University of Benin

Benin City, 300001 Nigeria.

All rights reserved.

Available online at http://www.tjpr.org

http://dx.doi.org/10.4314/tjpr.v11i6.7

Research Article

\title{
Methanol Extract of Myelophycus caespitosus Inhibits the Inflammatory Response in Lipopolysaccharide- stimulated BV2 Microglial Cells by Downregulating NF-kB via Inhibition of the Akt Signaling Pathway
}

\author{
Rajapaksha Gendara Prasad Tharanga Jayasooriya ${ }^{1}$, Chang-Hee Kang ${ }^{1}$, \\ Yeon-Jeong Jang ${ }^{1}$, Sang-Hyuck Kang ${ }^{1}$, Matharage Gayani Dilshara ${ }^{1}$, \\ Yung Hyun Choi ${ }^{2}$, Dong-Oh Moon ${ }^{3}$ and Gi-Young Kim ${ }^{1 *}$ \\ ${ }^{1}$ Laboratory of Immunobiology, Department of Marine Life Sciences, Jeju National University, Jeju 690-756, \\ ${ }^{2}$ Department of Biochemistry, College of Oriental Medicine, Dongeui University, Busan 614-054, ${ }^{3}$ Department of \\ Biology Education, College of Education, Gyeongsan, Gyeongbuk 712-714, Republic of Korea.
}

\begin{abstract}
Purpose: To determine whether the methanol extract of Myelophycus caespitosus (MEMC) downregulates the expression of pro-inflammatory mediators in lipopolysaccharide (LPS)-stimulated BV2 microglial cells.

Methods: Reverse transcription-polymerase chain reaction (RT-PCR) together with Western blot analysis was used to evaluate the expression of pro-inflammatory mediators such as nitric oxide (NO) and prostaglandin $\mathrm{E}_{2}$ $\left(\mathrm{PGE}_{2}\right)$ as well as their regulatory genes such as inducible NO synthase (iNOS) and cyclooxygenase-2 (COX2), in LPS-stimulated BV2 microglial cells. The level of NO production was analyzed using Griess reaction. The release of $\mathrm{PGE}_{2}$ was determined using sandwich enzyme-linked immunosorbent assay. The DNA-binding activity of nuclear factor-KB (NF-KB) was measured by electrophoretic mobility shift assay.

Results: MEMC inhibited LPS-induced pro-inflammatory mediators, $\mathrm{NO}$ and $\mathrm{PGE}_{2}$, as well as their respective genes, iNOS and COX-2, at both protein and mRNA levels, without any significant cytotoxicity. Treatment with MEMC also substantially reduced the LPS-induced DNA-binding activity of NF-KB and nuclear translocation of NF-KB subunits $p 65$ and $p 50$ via the inhibition of IKBa phosphorylation and degradation. MEMC promoted dephosphorylation of Akt that subsequently suppressed the DNA-binding activity of NF-KB in LPS-stimulated BV2 microglial cells.

Conclusion: Collectively, these data suggest that MEMC attenuates expression of pro-inflammatory mediators such as $\mathrm{NO}$ and $\mathrm{PGE}_{2}$ by suppression of their regulatory genes through the inhibition of Aktmediated NF-KB activity.
\end{abstract}

Keywords: Myelophycus caespitosus, Nitric oxide, Prostaglandin $E_{2}$, Nuclear factor-KB. 


\section{INTRODUCTION}

Inflammatory response functions in normal cells to protect against tissue wounds and microbial infections induced by biological, chemical or physical stimuli. However, an aberrant inflammatory response can lead to overexpression of pro-inflammatory mediators such as nitric oxide (NO) and prostaglandin $\mathrm{E}_{2}\left(\mathrm{PGE}_{2}\right)$, which can result in tissue destruction and organ damage $[1,2]$. Specifically, over-activated microglial cells exert self-cytotoxicity by secreting these proinflammatory mediators, and this plays an important role in the pathogenesis of central nervous system diseases such as Parkinson's and Alzheimer's diseases [3]. Therefore, agents that attenuate proinflammatory mediators in microglial cells may represent promising strategies for reducing brain injury and neurodegenerative disease. According to a recent study, inhibition of nuclear factor-kB (NF-kB) results in an anti-inflammatory response by downregulation of the expression of inducible NO synthase (iNOS) and cyclooxygenase-2 (COX-2) [4]. Targeting specific cell signaling pathways in the inflammatory process is expected to be a critical aspect in the treatment against inflammation-mediated diseases [5].

Marine algae have been extensively studied as they are a rich source of novel structural compounds that possess biological activity against malignant neoplasms, heart disease, high blood pressure, cerebrovascular disease, senility, diabetes and liver disease $[5,6]$. In recent reports, we also noted that many seaweed extracts significantly attenuate the expression of lipopolysaccharide (LPS)-stimulated proinflammatory mediators in microglial or macrophage cells and may therefore have the potential for modulating the LPS-induced inflammatory response [7-9]. Myelophycus caespitosus has been used as a traditional medicine in Northeastern Asia for treating inflammatory diseases, skin cancer, colon cancer, hematologic malignancy and skin whitening. Nevertheless, no scientific reports have yet investigated the anti-inflammatory properties of $M$. caespitosus.

This study focused on evaluating the effects of the methanol extract of $M$. caespitosus (MEMC) on the expression of $\mathrm{NO}$ and $\mathrm{PGE}_{2}$ and their respective regulatory genes iNOS and COX-2, in LPS-stimulated BV2 microglial cells.

\section{EXPERIMENTAL}

\section{Reagents and chemicals}

MEMC was purchased from Jeju HI-Tech Industry Development Institute (Jeju, Republic of Korea). LPS and 3-(4,5dimethylthiazol-2-yl)-2,5-diphenyl-tetrazolium bromide (MTT) were purchased from Sigma Chemical Co. (St. Louis, MO, USA). Rabbit anti-human antibodies against iNOS, COX-2, p65, p50, phospho (p)-IKBa, and IkBa were purchased from Santa Cruz Biotechnology (Santa Cruz, CA, USA). Rabbit anti-human antibodies against $\beta$-actin, c23, (p)-Akt and Akt were obtained from Cell Signaling (Beverly, MA, USA). Peroxidase-labeled antirabbit antibody was purchased from KOMA Biotechnology (Seoul, Republic of Korea) and LY294002 was purchased from Calbiochem (San Diego, CA, USA). Dulbecco's modified Eagle's medium (DMEM) and fetal bovine serum (FBS) were obtained from WelGENE Inc. (Daegu, Republic of Korea). Other chemicals used were purchased from Sigma.

\section{Cell culture and viability assay}

BV2 microglial cells were cultured at $37{ }^{\circ} \mathrm{C}$ in $5 \% \mathrm{CO}_{2}$ in DMEM supplemented with $5 \%$ FBS and antibiotics. In all experiments, cells were pre-treated with the indicated concentrations of MEMC $1 \mathrm{~h}$ before the addition of LPS $(1 \mu \mathrm{g} / \mathrm{ml})$ in serum-free DMEM. MTT assays were used to determine cell viability.

\section{NO assay}

BV2 microglial cells $\left(1 \times 10^{5}\right.$ cells $\left./ \mathrm{ml}\right)$ were plated onto 24-well plates and pretreated with 
the indicated concentrations of MEMC for $1 \mathrm{~h}$ prior to stimulation with $1 \mu \mathrm{g} / \mathrm{ml}$ of LPS for 24 $h$. The cell supernatants were collected and assayed for NO production using Griess reagent. Briefly, the samples were mixed with equal volume of Griess reagent (1 \% sulfanilamide in $5 \%$ phosphoric acid and 0.1 $\%$ naphthylethylenediamine dihydrochloride) and then incubated at room temperature for 5 min. The absorbance was measured at 540 $\mathrm{nm}$ on a microplate reader (MULTISKAN EX, Thermo Electron Corporation, Marietta, $\mathrm{OH}$, USA). Nitrite concentration was determined from a sodium nitrite standard curve.

\section{Measurement of $\mathrm{PGE}_{2}$}

The expression levels of $\mathrm{PGE}_{2}$ were measured by enzyme-linked immunosorbent assay (ELISA) kit (R\&D Systems, Minneapolis, MN, USA) according to the manufacturer's instructions. Briefly, BV2 microglial cells $\left(2 \times 10^{5}\right.$ cells $\left./ \mathrm{ml}\right)$ were plated in 24-well plates and pretreated with the indicated concentrations of MEMC for $1 \mathrm{~h}$ prior to stimulation with $1 \mu \mathrm{g} / \mathrm{ml}$ of LPS for 24 h. One hundred microliters of culture media were collected for the determination of $\mathrm{PGE}_{2}$ concentrations by ELISA.

\section{Reverse transcriptase polymerase chain reactions (RT-PCR)}

Total RNA was extracted from BV2 microglial cells using Easy-blue reagent (iNtRON Biotechnology, Sungnam, Republic of Korea) according to the manufacturer's instruction. One microgram of RNA was reversetranscribed using MMLV reverse transcriptase (Bioneer, Daejeon, Republic of Korea). Then, cDNA was amplified by PCR using specific primer iNOS (forward 5'-cct cct cca ccc tac caa gt-3' and reverse 5'-cac cca aag tgcttc agt ca-3'), COX- 2 (forward 5'-aag act tgc cag gct gaa ct-3' and reverse 5'-ctt ctg cag tcc agg ttc aa-3') and $\beta$-actin (forward 5'tgt gat ggt ggg aat ggg tca g- 3 ' and reverse 5'-ttt gat gtc acg cac gat ttc c-3'). The following PCR conditions were applied: COX-
2 and iNOS, 25 cycles of denaturation at 94 ${ }^{\circ} \mathrm{C}$ for $30 \mathrm{~s}$, annealing at $59^{\circ} \mathrm{C}$ for $30 \mathrm{~s}$ and extended at $72^{\circ} \mathrm{C}$ for $30 \mathrm{~s}$; $\beta$-actin, 23 cycles of denaturation at $94^{\circ} \mathrm{C}$ for $30 \mathrm{~s}$, annealing at $57^{\circ} \mathrm{C}$ for $30 \mathrm{~s}$ and extended at $72^{\circ} \mathrm{C}$ for $30 \mathrm{~s}$. $\beta$-actin was used as an internal control to evaluate relative expression of COX-2 and iNOS.

\section{Western blot analysis}

Total cell extracts were prepared using PROPREP protein extraction solution (iNtRON Biotechnology). The preparation of cytosolic and nuclear extracts was conducted using NE-PER nuclear and cytosolic extraction reagents (Pierce, Rockford, IL, USA). Cell extracts were separated on polyacrylamide gels and then standard procedures were used to transfer them to the nitrocellulose membranes. The membranes were developed using an ECL reagent (Amersham, Arlington Heights, IL, USA).

\section{Electrophoretic mobility shift assay (EMSA)}

DNA-protein binding assays were carried out with nuclear extract. Synthetic complementtary NF-KB binding oligonucleotides (5'-AGT TGA GGG GAC TTT CCC AGG C-3') were 3'-biotinylated using the biotin 3'-end DNA labeling kit (Pierce, Rockford, IL, USA) according to the manufacturer's instructions. Assays were performed using a Lightshift EMSA Optimization kit (Pierce) according to the manufacturer's protocol.

\section{Statistical analysis}

All data were derived from at least three independent experiments. Statistical analyses were conducted using SigmaPlot software (version 11.0) Values were presented as mean \pm SE. Significant differences between the groups were determined using one-way ANOVA, with statistical significance set at $p<0.05$. 


\section{RESULTS}

\section{MEMC is not cytotoxic to BV2 microglial cells}

To evaluate the effects of MEMC on the viability of BV2 microglial cells, we incubated the cells with various concentrations of $\operatorname{MEMC}(0,2.5,5.0,7.5$ and $10.0 \mu \mathrm{g} / \mathrm{ml})$ for 24 $\mathrm{h}$ with or without incubation with LPS. Cell viability was assessed by the MTT assay and showed that MEMC did not exert significant cytotoxicity at all concentrations tested (Fig 1). Solvent control (0.1\% DMSO) or LPS alone did not exert significant cytotoxicity, but a high concentration of MEMC of $20.0 \mu \mathrm{g} / \mathrm{ml}$ substantially induced cell death (data not shown). Therefore, concentrations of MEMC ranging from 0.0 to $10.0 \mu \mathrm{g} / \mathrm{ml}$ were selected for further studies.

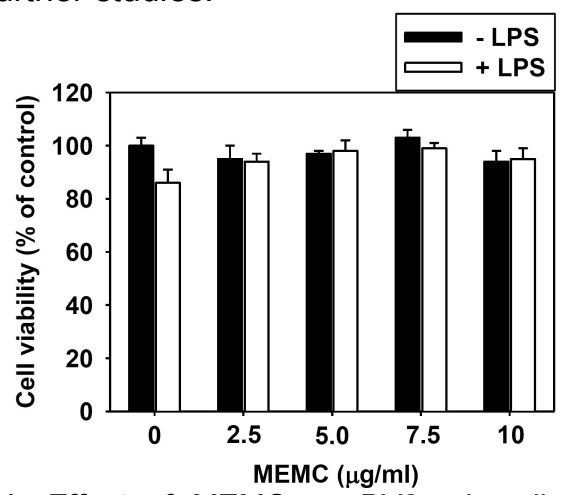

Fig 1: Effect of MEMC on BV2 microglial cell viability. Cells $\left(1 \times 10^{5}\right.$ cells $\left./ \mathrm{ml}\right)$ were incubated with the indicated concentrations of MEMC $1 \mathrm{~h}$ before LPS $(1.0 \mu \mathrm{g} / \mathrm{ml})$ treatment for $24 \mathrm{~h}$. Data are presented as mean $\pm \mathrm{SE}, \mathrm{n}=3 ;{ }^{*} p<0.05$.

\section{MEMC suppresses NO and $\mathrm{PGE}_{2}$ production}

To confirm the anti-inflammatory effects of MEMC in LPS-stimulated BV2 microglial cells, we investigated the production of NO using the Griess reagent assay. Fig $2 \mathrm{~A}$ shows that LPS significantly increases NO production to $14.1 \pm 1.2 \mu \mathrm{M}$; however, pretreatment with MEMC decreased LPSinduced NO production to $10.4 \pm 0.8 \mu \mathrm{M}, 7.8$ $\pm 0.7 \mu \mathrm{M}, 6.2 \pm 0.8 \mu \mathrm{M}$ and $4.1 \pm 0.3 \mu \mathrm{M}$ in a dose-dependent manner. In particular, the highest concentration of MEMC reduced the $\mathrm{NO}$ levels comparable to that of the control group $(3.2 \pm 0.3 \mu \mathrm{M})$. In parallel, ELISA was performed to assess the effect of MEMC on LPS-stimulated secretion of $\mathrm{PGE}_{2}$ in $\mathrm{BV} 2$ microglial cells. Similar to NO, MEMC significantly attenuated LPS-mediated $\mathrm{PGE}_{2}$ production in a dose-dependent manner (Fig 2B). Following LPS stimulation, $\mathrm{PGE}_{2}$ levels reached $1324 \pm 35 \mathrm{pg} / \mathrm{ml}$. However, a high concentration of MEMC $(10 \mu \mu \mathrm{g} / \mathrm{ml})$ completely reduced the $\mathrm{PGE}_{2}$ levels to $421 \pm$ $12 \mathrm{pg} / \mathrm{ml}$, comparable to the levels of the control group $(311 \pm 21 \mathrm{pg} / \mathrm{ml})$. These data suggest that MEMC suppresses proinflammatory mediators such as $\mathrm{NO}$ and $\mathrm{PGE}_{2}$ in LPS-stimulated BV2 microglial cells.

A

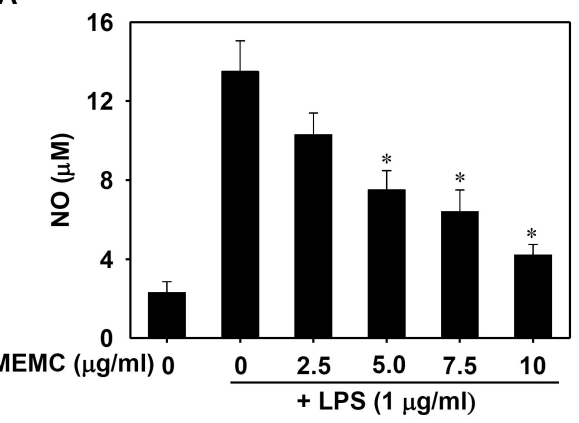

B

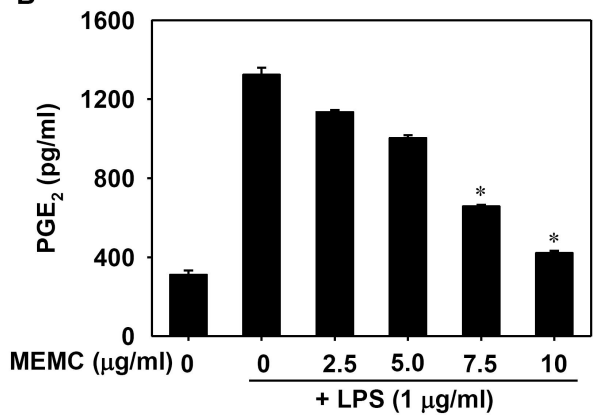

Fig 2: Effect of MEMC on LPS-induced NO (A) and $\mathrm{PGE}_{2}(\mathrm{~B})$ production in BV2 microglial cells; Cells $\left(1 \times 10^{5}\right.$ cells $\left./ \mathrm{ml}\right)$ were treated with the indicated concentrations of MEMC $1 \mathrm{~h}$ before LPS $(1.0 \mu \mathrm{g} / \mathrm{ml})$ treatment for $24 \mathrm{~h}$. (A) The levels of NO were determined using Griess reagent and a standard curve was constructed using $\mathrm{NaNO}_{2}$ in culture medium. (B) The levels of $\mathrm{PGE}_{2}$ in the media were detected using a specific enzymelinked immunosorbent assay. Data are presented as mean $\pm \mathrm{SE}, \mathrm{n}=3$; ${ }^{*} p<0.05$. 


\section{MEMC attenuates iNOS and COX-2 expression}

To investigate the expressional mechanism of pro-inflammatory mediators such as NO and $\mathrm{PGE}_{2}$ in LPS-induced BV2 microglial cells, we measured the expression of their respective regulatory genes, iNOS and COX2 , both the protein and mRNA level using western blot analysis and RT-PCR. LPS treatment increased the expression of iNOS and COX-2 (Fig 3A) as well as their mRNA (Fig 3B). However, MEMC treatment significantly inhibited LPS-induced iNOS and COX-2 expression at both the mRNA and protein level. MEMC alone had no effect on the expression of these proteins and genes. These data indicate that MEMC regulates the transcription of iNOS and COX-2 in a LPSdependent manner.
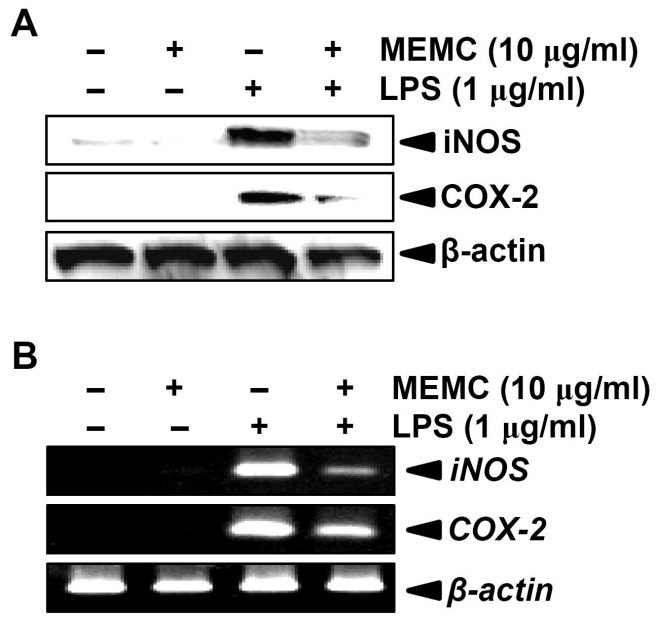

Fig 3: Effect of MEMC on LPS-induced iNOS and COX-2 protein $(A)$ and mRNA $(B)$ expression in BV2 microglial cells. Cells $\left(1 \times 10^{5}\right.$ cells $\left./ \mathrm{ml}\right)$ were incubated with MEMC $(10 \mu \mathrm{g} / \mathrm{ml}) 1 \mathrm{~h}$ before LPS $(1.0 \mu \mathrm{g} / \mathrm{ml})$ treatment for $6 \mathrm{~h}$. (A) Cell lysates were resolved on SDS-polyacrylamide gels, transferred to nitrocellulose membranes, and probed with antibodies against iNOS or COX-2. (B) Total RNA was isolated and RT-PCR analyses of iNOS and COX-2 were performed. Note: $\beta$-Actin was used as an internal control for the RT-PCR and Western blot analysis.

\section{MEMC modulates LPS-stimulated NF-KB activity}

NF-KB activation is essential to transactivate LPS-induced iNOS and COX-2 gene expression [10]. We measured the DNAbinding activity of NF-KB and the nuclear translocation of NF-KB subunits p65 and p50 as well as IKB degradation and phosphorylation. Treatment with LPS significantly increased DNA-binding activity of NF-KB as measured by the EMSA (Fig 4A). However, pretreatment with MEMC completely reduced LPS-induced DNAbinding activity of NF-KB. In a parallel experiment, we found that LPS reduces the expression of p65 and p50 in the cytosolic fraction, and this correlated with an increase in phosphorylated $\mathrm{I} \mathrm{KB}$ as measured by western blot analysis (Fig 4B). However, prior treatment with MEMC maintained stable p65 and p50 levels in the cytosolic fractions and decreased the amount of phosphorylated IKB. In addition, we found that LPS treatment induced the nuclear translocation of p65 and p50; however, pretreatment with MEMC resulted in a decrease of these NF-KB subunits in the nuclear fraction (Fig 4C). These data indicate that MEMC inhibits NFKB activity by suppressing IKB-mediated nuclear translocation of NF-KB.

\section{MEMC inhibits LPS-stimulated NF-KB activity through suppression of Akt phosphorylation}

The Akt signaling pathway has been shown to regulate pro-inflammatory genes such as iNOS and COX-2 through activation of NF-KB [11]. Therefore, we examined the effect of MEMC on Akt phosphorylation in LPSstimulated BV2 microglial cells using western blot analysis. Phosphorylated Akt was significantly increased in LPS-stimulated BV2 microglia cells; however, MEMC treatment produced an inhibition of Akt phosphorylation (Fig 5A). 
Jayasooriya et al
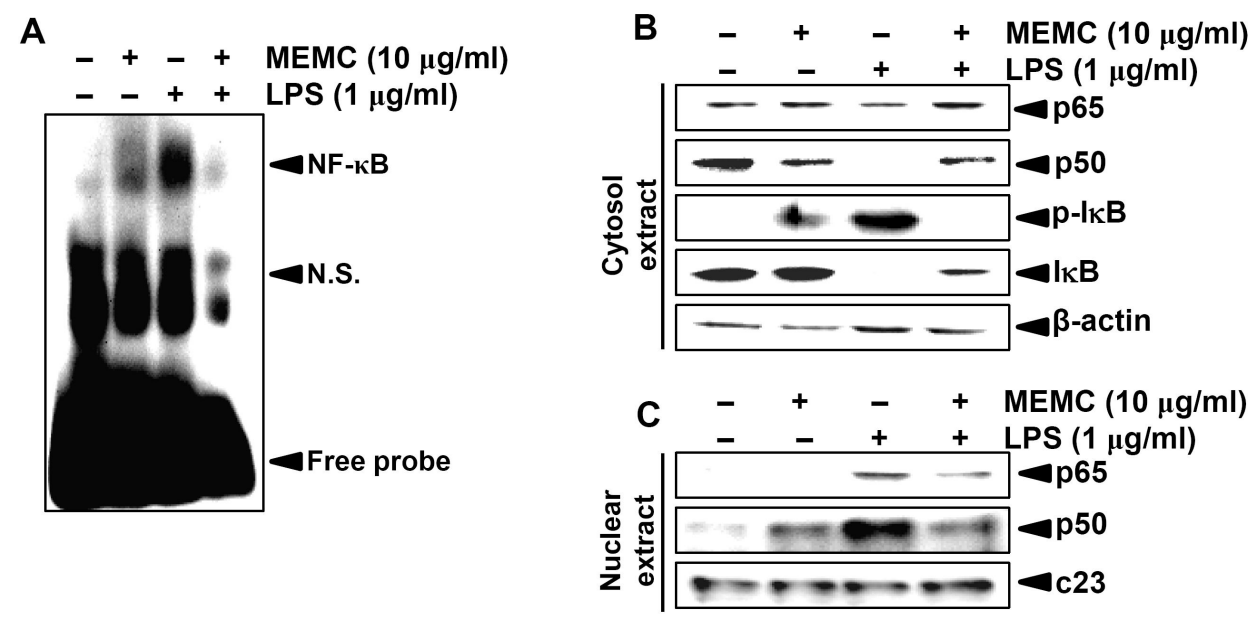

Fig 4: Effect of MEMC on NF-KB activity in LPS-stimulated BV2 microglial cells. Cells were pretreated with MEMC $(10 \mu \mathrm{g} / \mathrm{ml}) 1 \mathrm{~h}$ before stimulation with LPS $(1.0 \mu \mathrm{g} / \mathrm{ml})$ for $30 \mathrm{~min}$. (A) The nuclear extracts were assayed for NF-KB activity by EMSA. The cytosolic (B) and nuclear (C) extracts were prepared to determine the levels of p65, p50, phosphor-ІкBa and IkBa by western blot analysis. Note: $\beta$-Actin and c23 were used as an internal control for Western blot analysis. N.S. = non-specific.

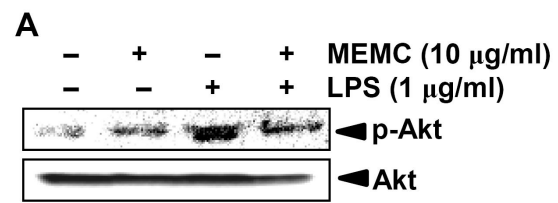

B

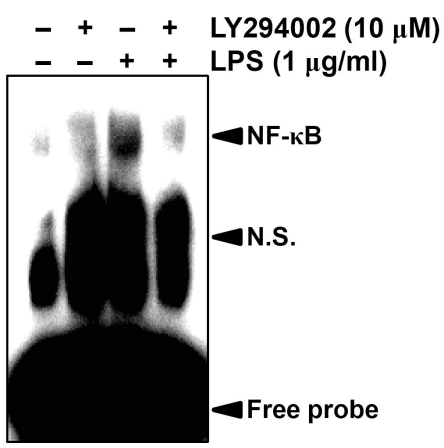

Fig 5: Effect of MEMC on Akt phosphorylation in LPS-stimulated BV2 microglial cells. (A) Cells were pretreated with MEMC $(10 \mu \mathrm{g} / \mathrm{ml}) 1 \mathrm{~h}$ before stimulation with LPS $(1.0 \mu \mathrm{gg} / \mathrm{ml})$ for $30 \mathrm{~min}$. Western blot analysis was performed to determine Akt phosphorylation. (B) Cells were treated with LY294002 $(20 \mu \mathrm{M}) 1 \mathrm{~h}$ before LPS $(1.0 \mu \mathrm{g} / \mathrm{ml})$ treatment for $30 \mathrm{~min}$. EMSA measured NF-kB binding to its DNA promoter region in the nuclear protein extract. N.S. = non-specific.
To verify that Akt activity is directly involved in NF-KB activation, we investigated the effect of the Akt inhibitor LY294002 on LPSstimulated NF-KB DNA-binding activity. We found that treatment with LY294002 substantially reduced NF-KB-DNA binding in nuclear extracts (Fig 5B). These data indicate that MEMC inhibits LPS-induced NF-KB activation by inhibiting Akt phosphorylation

\section{DISCUSSION}

Several studies have reported that MEMC possesses anti-allergic and anti-cancer activities [12,13]. Nevertheless, there have been no reports on the effect of MEMC in LPS-stimulated inflammatory response. Therefore, we studied the anti-inflammatory properties of MEMC in LPS-stimulated BV2 microglial cells. We first found that MEMC attenuates $\mathrm{NO}$ and $\mathrm{PGE}_{2}$ production and the expression of their respective regulatory genes, iNOS and COX-2, at both the mRNA and protein levels. In addition, we presented data that suggest that MEMC inhibits iNOS and COX-2 expression by suppressing NF-KB activity through the inhibition of Akt phosphorylation. 
Microglias are glial cells that function in the central nervous system's immune response against bacterial infection [14]. Microglias represent $20 \%$ of the total glial cell population in the mature brain [15]. When stimulated with LPS, microglias release $\mathrm{NO}$ and $\mathrm{PGE}_{2}$, which mediate traumatic brain injury following cerebral stroke [16]. Moreover, there is extensive evidence indicating that neural damage is absent in iNOS-deficient mice [17] and that inhibition of COX-2 expression after stroke in vivo exerts neuroprotective effects [18]. Therefore, the inhibition of proinflammatory mediators such as $\mathrm{NO}$ and $\mathrm{PGE}_{2}$ is a potential therapeutic approach against neurodegenerative diseases. Our data demonstrated that MEMC significantly attenuates the expression of iNOS and COX2 as well as their respective gene products in LPS-stimulated BV2 microglial cells. We hypothesize that MEMC exerts neuroprotective effects by inhibiting LPS-induced inflammatory responses.

$\mathrm{NF}-\mathrm{KB}$ is known to play an important role in the regulation of pro-inflammatory genes such as iNOS and COX-2 [4]. Therefore, targeting the NF-kB pathway represents a potential strategy to treat and prevent inflammatory diseases such as asthma and nervous disorders [19]. In the present study, we found that MEMC inhibits NF-KB activity by suppressing nuclear translocation of NFKB subunits $p 65$ and p50 via the inhibition of IKB phosphorylation and degradation. To further explore NF-kB regulation, we investigated the relationship between Akt dephosphorylation and regulation of NF-KB activity, as it has been reported that many anti-inflammatory mediators are modulated by the Akt-dependent NF-kB signaling pathway [11]. In this study, MEMC significantly inhibited Akt phosphorylation, which suppresses NF-kB activation. These data demonstrate the potential of MEMC as a pharmaceutical agent for LPS-induced inflammatory disease. Nevertheless, recent studies showed that mitogen-activated protein kinases (MAPKs) and reactive oxygen species (ROS) are effector molecules that regulate NF-kB-dependent inflammatory reactions [20,21], although the role of ROS in NF-KB regulation remains controversial [22]. In addition, the transcription factor, AP-1, is also involved in the regulation of inflammation-associated gene expression in LPS-stimulated alveolar macrophages [23]. Therefore, further studies are required to elucidate the role of AP-1 and MAPKs in LPS-induced inflammatory responses.

\section{CONCLUSION}

Our data demonstrate that MEMC inhibits anti-inflammatory mediators such as $\mathrm{NO}$ and $\mathrm{PGE}_{2}$, and their respective regulatory genes iNOS and COX-2 in LPS-stimulated BV2 microglial cells. This anti-inflammatory effect results from the inhibition of Akt phosphorylation and the subsequent attenuation of NF-kB activation.

\section{ACKNOWLEDGEMENT}

This research was supported by a project funded by the Ministry of Land, Transport and Maritime Affairs (Grant no. 20088137).

\section{COMPETING INTERESTS}

The authors report no conflict of interest and they alone are responsible for the contents of this work.

\section{REFERENCES}

1. Lin WW, Karin M. A cytokine-mediated link between innate immunity, inflammation, and cancer. $J$ Clin Invest 2007; 117: 1175-1183.

2. Lawrence $T$, Willoughby $D A$, Gilroy DW. Antiinflammatory lipid mediators and insights into the resolution of inflammation. Nat Rev Immunol 2002; 2: 787-795.

3. Perry VH, Gordon S. Macrophages and microglia in the nervous system. Trends Neurosci 1988; 11: 273-277.

4. Baeuerle PA, Baichwal VR. NF-kB as a frequent target for immunosuppressive and antiinflammatory molecules. Adv Immunol 1997; 65: 111-137.

5. Garcia-Lafuente A, Guillamon E, Villares A, Rostagno MA, Martinez JA. Flavonoids as antiinflammatory agents: implications in cancer and 
cardiovascular disease. Inflamm Res 2009; 58: 537-552.

6. Li Y, Qian ZJ, Ryu B, Lee SH, Kim MM, Kim SK. Chemical components and its antioxidant properties in vitro: An edible marine brown alga, Ecklonia cava. Bioorg Med Chem 2009; 17: 1963-1973.

7. Jayasooriya RGPT, Kang $\mathrm{CH}$, Park SY, Choi $\mathrm{YH}$, Moon DO, Kim GY. Methanol extract Polyopes lancifolius inhibits the expression of proinflammatory mediators in LPS-stimulated BV2 microglia cells via downregulation of the NF-KB pathway. Trop J Pharm Res 2012; 11: 43-50.

8. Kang $\mathrm{CH}$, Choi YH, Park SY, Kim GY. Antiinflammatory effects of methanol extract of Codium fragile in lipopolysaccharide-stimulated RAW 264.7 cells. J Med Food 2012; 15: 44-50.

9. Jayasooriya RGPT, Moon DO, Choi YH, Yoon $\mathrm{CH}$, Kim GY. Methanol extract of Hydroclathrus clathratus inhibits production of nitric oxide, prostaglandin E2 and tumor necrosis factor- $\alpha$ in lipopolysaccharide-stimulated BV2 microglial cells via inhibition of NF-KB activity. Trop $J$ Pharm Res 2011; 10: 723-730.

10. Lee AK, Sung SH, Kim YC, Kim SG. Inhibition of lipopolysaccharide-inducible nitric oxide synthase, TNF- $\alpha$ and COX-2 expression by sauchinone effects on $I K B \alpha$ phosphorylation, $C / E B P$ and $A P-1$ activation. $B r J$ Pharmacol 2003; 139: 11-20.

11. Madrid LV, Wang CY, Guttridge DC, Schottelius AJ, Baldwin Jr AS, Mayo MW. Akt suppresses apoptosis by stimulating the transactivation potential of the Rel A/p65 subunit of NF-KB. Mol Cell Biol 2000; 20: 1626-1638.

12. Kakegawa $H$, Matsumoto $H$, Satoh $T$. Inhibitory effects of hydrangenol derivatives on the activation of hyaluronidase and their antiallergic activities. Planta Med 1988; 54: 385-389.

13. Koji T, Satoshi I, Ako I, Hajime K, Keita N, Yoshihiro $K$. Inhibitory effect of proanthocyanidins isolated from barley bran on hyaluronidase activity, soybean lipoxygenase activity and complementary activity. Nippon Shokuhin Kagaku Kogaku Kaishi 1999; 46: 521-527.
14. Barron KD. The microglial cell. A historical review. J Neurol Sci 1995; 134: 57-68.

15. Boje KM, Arora PK. Microglia-produced nitric oxide and reactive nitrogen oxides mediate neuronal cell death. Brain Res 1992; 587: 250-256.

16. Chao CC, Hu S, Molitor TW, Shaskan EG, Peterson PK. Activated microglia mediate neuronal cell injury via a nitric oxide mechanism. J Immunol 1992; 149: 2736-2741.

17. Ono Kenji, Suzuki H, Sawada M. Delayed neural damage is induced by iNOS-expressing microglia in a brain injury model. Neurosci Lett 2010; 473: 146-150.

18. Araki E, Forster C, Dubinsky JM. Ross ME, ladecola C. Cyclooxygenase-2 inhibitor ns-398 protects neuronal cultures from lipopolysaccharideinduced neurotoxicity. Stroke 2001; 32: 2370-2375.

19. Wong ET, Tergaonkar V. Roles of NF-KB in health and disease: mechanisms and therapeutic potential. Clin Sci 2009; 116: 451-465.

20. Chi $H$, Barry SP, Roth RJ, Wu JJ, Jones EA, Bennett AM, Flavell RA. Dynamic regulation of pro- and anti-inflammatory cytokines by MAPK phosphatase 1 (MKP-1) in innate immune responses. Proc Natl Acad Sci USA 2006; 103 : 2274-2279.

21. Islam MS, Yoshida $H$, Matsuki N, Ono K, Nagasaka $R$, Ushio $H$, Guo $Y$, Hiramatsu $T$, Hosoya $T$, Murata $T$, Hori M, Ozaki $H$. Antioxidant, free radical-scavenging, and NF-KB-inhibitory activities of phytoseryl ferulates: structureactivity studies. J Pharmacol Sci 2009; 111: 328-337.

22. Chandel NS, Trzyna WC, McClintock DS, Schumacker PT. Role of oxidants in NF-KB activation and $T N F-\alpha$ gene transcription induced by hypoxia and endotoxin. J Immunol 2000; 165: 1013-1021.

23. Chen CY, Peng WH, Tsai KD, Hsu SL. Luteolin suppresses inflammation-associated gene expression by blocking NF-KB and $A P-1$ activation pathway in mouse alveolar macrophages. Life Sci 2007; 81: 1602-1614. 